\title{
INTRODUCING THE CONCEPT OF FIRST AND LAST VALUE TO AID LEAN DESIGN: LEARNING FROM SOCIAL HOUSING PROJECTS IN CHILE
}

\author{
Christine Pasquire $^{1}$ and Jose Salvatierra-Garrido ${ }^{2}$
}

\begin{abstract}
Value for the customer through efficient production processes is a fundamental principle of Lean. In Lean Construction, Value to customers is largely delivered through project planning and control activities only. Thus, it can be argued that Lean Construction overlooks the opportunity to address Value from the early stages of a project. Aimed at improving this, Lean Design arose as a new approach for design management promoting customer and end user involvement from the early stage of projects. However, even here environmental \& social issues are postponed over individual requirements. As a result, Lean potential in general skips the opportunity to address Value from a wider perspective in which the return of Value from the construction industry to society is considered. This paper proposes dividing the wider understanding of the performance of the (global) built environment from the particular (local) project requirements calling the former First Value and the latter Last Value. The theory is triangulated through observation of how a developing country (Chile) is resolving social issues through the use of the built environment. The work described develops Lean Design Management by providing a clearer vision of Value to reduce waste and aid sustainability in the built environment.
\end{abstract}

KEY WORDS: Value, Lean Construction, Lean Design, Lean Design Management

\section{Introduction}

There is a tendency in Lean thinking to link the concept of Value to waste reduction. This is illustrated in Lean manufacturing where waste has been defined as "specifically any human activity which absorbs resources but creates no value" (Womack and Jones, 2003:15). This idea also prevails in Lean Construction (LC) where adding value and reducing waste have been recognised as activities central to the delivery of products that satisfy customer requirements. "Value management in Lean production is an attempt to maximise value and eliminate waste" (Bae and Kim, 2007:314). As a result LC efforts have focused on improving site activities through changed project execution processes - reducing the human activity that absorbs resource and therefore, waste. A question remains over the relationship of reducing waste in this way to actually delivering Value. It is recognised that many problems such as excessive costs, unsuccessful final results, wasteful processes, customer dissatisfaction, deficient product attributes, etc. - have their roots in inadequate management of the early design and detailing phases of a construction project (Love \& Li 2000; Emmitt et al. 2004; Brookfield et al. 2004; Thyssen et al. 2008). Lean

1 Professor of Lean Project Management, School of Architecture, Design and the Built Environment, Nottingham Trent University, UK, Phone +44 (0)115 848 2095, Christine.Pasquire@ @tu.ac.uk

2 PhD Student, Department of Civil and Building Engineering, Loughborough University, UK, Phone +44 (0)1509 222884, J.L.Salvatierra-Garrido@lboro.ac.uk 
thinking in Design and Design Management improves the design process through customer and end user involvement from an early stage of the project (Tilley, 2005). Additionally Lean Design itself aims “to improve the 'manufacturability' of a product...concerned with generating unique value for the customer..." (Brookfield et al. 2004:1). Consequently, Lean thinking demonstrates a close relationship between Value and customer satisfaction, where the customer is commonly understood to be the person/organisation/body that pays for the end product - in construction this product is a large physical structure usually occupying or connecting land e.g. bridges can be argued to occupy air space. This understanding of customer extends into the design perspective where most efforts to deliver Value have focused on satisfying the bill payer. Authors such as Emmitt et al. (2005), Bertelsen and Emmitt, (2005) have suggested society is a potential customer, but they acknowledge that particular interests still predominate over social issues. The importance of developing a wider view of Value for construction is being driven by the need for sustainability generally and the particular role construction within society. There is no counter argument to the statement that the activities of the human species ALL rely on some form of constructed facility and the more developed a country is the more this is true. It is also apparent that construction products (buildings and infrastructure) have an impact outside the immediate circle of stakeholders and that this impact has a very significant lifespan often way beyond the designed use or function. There are many examples of "state of the art" developments that grew up to become ghettos; centres of crime, poor health and deprivation absorbing national resource, contributing little and therefore "wasteful". To avoid or break this wasteful decay cycle of development requires a changed view of the role of the construction sector within society - the First role of the built environment must be to contribute to society by supporting all those activities be they public or commercial, individual or group. This is challenging in several ways, the majority of society has no "voice" in the traditional construction design process in the same way as the environment has no voice - of the sustainable triple bottom line, the economic dominates. Also, there is little concerted effort to collect, understand and use knowledge about the lifecycles of development to influence the design and management of the built environment as a whole even where planning and regulation exist. Such provide checks and balances to aspects of development but joined up urban and rural planning governing more than blocks of land use is limited in the developed world - all major decisions were made long ago. The situation is different in the developing world where opportunities exist to design a built environment that supports society and impacts directly on the national economy. Here the relationship between these is more visible and cause and effect over time can be measured.

\section{Research Methodology}

The research described in this paper comprised a desktop literature review and a case study comprising two Social Housing Projects (SHP) in Santiago, Chile. These projects have been initiated in response to a new social housing policy which intended to insert the homeless population into local society. This policy demanded more than simply providing accommodation of a stated quality but considered social impact by requiring the developments to contribute to the society they are to become integrated into. The literature review has sought to explain how this policy fits into the accepted understanding of value in construction. The attributes of the case study projects have been identified through examination of the SHP documentation. Interviews with a 
variety of stakeholders were used to triangulate the findings from literature and illustrate the inclusion of social value into the development of the built environment.

\section{Review of Value in Construction Literature}

The concept of Value is widely discussed and, according to Leszinski and Marn (1997) "one of the most overused and misused concepts of social sciences in general and in management literature in particular". Lean construction authors agree it is difficult to discuss and define (Bertelsen and Koskela, 2004:6; Emmitt et al. 2004:3). Previous research (Salvatierra-Garrido et al. 2009; Salvatierra-Garrido et al, 2010) aiming to better understand the concept of Value from a construction perspective revealed two key findings:

1. It is necessary to differentiate between Value and values. These concepts are commonly misunderstood as the one being the plural of the other. Value can be understood as what a customer places upon a product (Wandhal, 2005), whereas values are innately subjective; they make human guidelines (ethical and ideological) evident, representing the value system of an individual, organisation or society as a whole (Amis et al, 2002; Thomson et al. 2003,a; Kelly et al. 2004; Thomson and Austin, 2006; Glew 2009:675); and

2. Value has been mainly understood as an objective concept with numerous parameters such as cost, quality, function, etc. have been associated to Value delivery (Green 1997; Thomson et al 2003,a; Thomson et al. 2003,b). Some subjective parameters such as design have been linked to this concept, and architects are universally considered to be the carriers of the customer Value perspective. (Erikshammar et al. 2010). To address Value in the construction sector in a better way, the full range of its diverse features should be considered: objectivity, subjectivity, relativity, dynamism, context dependence (Wandahl, 2005).

\section{Value from a Lean Construction perspective}

From the beginning of LT in manufacturing sector, the word Value has been introduced as a concept to analyse the performance of production processes. Thus, in the book "Lean Thinking" the concept of Value was defined as "a capability provided to a customer at the right time and at an appropriate price, as defined in each case by the customer." (Womack and Jones, 1996: 311). In addition, it has been recognised that LT practices "must start with a conscious attempt to precisely define value in terms of specific products with specific capabilities offered at specific price through a dialogue with specific customers" (Womack and Jones, 2003:19). When LT has been adapted to the environment of the construction sector, this conception of Value as materials, parts or products has been broadly criticised (Koskela, 2000 and 2004). However, the LC perspective of Value still is strongly influenced by the Lean production theory. In his deep investigation, Koskela (2000) distinguished three theoretical models to show construction as a production process: Transformation, Flow and Value generation. As a consequence TFV is presented as a theory of production for the construction sector. To date LC experience has demonstrated that the concepts of Transformation and Flow have been widely applied across the supply chain activities. Transformation meaning where input is transformed into output along on-site activities, and Flow in the sense of improvement in control and organisation and planning activities. However, value generation has been less explored focused 
only on the fulfillment of particular customer's requirements, through control and planning of construction activities. Therefore, Value has been associated with objective parameters, such as waste reduction, cost, quality, time, function etc. of activities performed at project level intended only to satisfy customer requirements

\section{Value from a Lean Design Management Perspective}

When LT has been translated as a management process for design, activities have been targeted mainly towards improving the manufacturability of products. Thus, the early stages of a project have focused on coordination and flow of information, and on the development of designs capable of satisfying technological, functional and operational requirements (Brookfield et al. 2004). In addition, the earlier phases of Lean Design should generate options to enhance client values and go beyond the mundane to create "real value for client and building users alike" (Emmitt et al. 2004:2). To avoid problems arising in the construction stage, Lean Design Management has also been linked to the improvement of communication and the decision making process. In this way, interactive workshops with participation of stakeholders become a central activity to create consensus in the differing Value judgements. These activities are understood as an opportunity to reduce future uncertainty and minimise waste (Emmitt et al. 2004). The interaction of different stakeholders allows consideration of the notion of an expanded customer/client. Different bodies such as owners, constructors, subcontractors, end users, authorities, etc. contribute with different Value judgments from early stage of projects. This expanded customer notion provides an opportunity to consider society as a potential customer. In this way, some Lean Design authors have emphasised the importance of considering society and social aspects:

- "The client often represents a lot of different stakeholders (the users, the investor, the owner etc.), and furthermore when we build we affect our neighbour and the surroundings (city/landscape etc.) and they all have a different set of values and interests in the project." (Emmitt, Sander and KirkChristoffersen, 2005: 59).

- "Looking closer at the nature of the client, one may identify behind the façade an organisation, which during the project execution should represent the interests of three distinct client groups - the owners, the users and society. These three groups of interest each value different things at different time in the life of the building." (Bertelsen \& Emmitt, 2005:74).

So Lean Design Management clearly includes ensuring timely interaction of the appropriate parties. Moreover, other authors in the field of LC have underlined the potential of including society from a Lean perspective (Koskela, 2000; Dugnas and Oterhals, 2006; Höök, 2006; Koskela et al. 2008; Forsberg and Saukkoriipi, 2007; Alves and Tsao, 2007). Ballard (2008) believes there is a growing tendency to consider sustainability in construction design and that whole life issues are becoming more important. Despite the strength of these calls, general practice continues to postpone social issues for particular interests. Ballard (2008) adds that using a lean project delivery system to manage definition and design of projects will deliver Value within the constraints. In addition, the supply chain commonly understands the customer as the "one who pays" for satisfying particular requirements. As a result, social issues continue to be included only if they are important from the bill payer's perspective - one would expect this to be strongest in public sector construction. To 
address this, the needs of society should be integrated into the agenda of the bill payer in a way that provides a voice to the voiceless. It is proposed that Value is visualised through the introduction of two new concepts: First Value and Last Value in order to elevate social issues in design management.

\section{First and Last Value Concepts}

Lean thinking requires an end to end view of the system under consideration. The construction sector is compartmentalised - there are connections but little integration between design, build/construct and repair/maintain. To make matters worse, there is a clear divide between these 3 activities and the planning of the built environment and the use of the built environment. This separation is entirely responsible for the absence of social issues on the bill payer's agenda - what has built environment planning and use to do with the construction customer and supply chain other than to constrain choice? As a result there is a general failure to recognise the impact of the construction sector output as a whole on society (and vice versa) beyond that required by planning legislation. The concepts of First and Last Value intend to (re)connect society with the construction process and evidence a return of Value to society as a result. These concepts recognise Value as an "oscillating" phenomenon. That means, Value delivered for a particular building project impacts society as a whole and consequently the judgements of Value for future building projects, and so on and so forth (Salvatierra-Garrido et al, 2010). It has been proposed that architects are the carriers of customer value (Erikshammar et al. 2010) - the detail of First and Last Value however are too big for one person to know and own. Responsibility for First and Last Value belongs with the design manager who needs to ensure parties with the appropriate knowledge are engaged in the process. A Lean Design Manager should have an end to end view clearly recognising when and how to engage with planners and/or politicians as well as special interest groups, end users and members of the supply chain.

First Value: This concept considers Value delivery in a wide sense, where the impact of the construction industry over society is considered. This classification of Value proposes an expansion of common customer-focused perspectives to cover broader aspects - buildings and infrastructure as social assets, development as it contributes to cures for both environmental \& social issues (e.g. climate change, sustainability, pollution, reducing crime, increasing educational levels, social network insertion, socialisation, etc.). Here the widest sense of societal benefit includes sustaining the environment and the economy for human survival and development. First Value therefore expresses societal goals, is high level, politically led and somewhat intangible.

Last Value: This concept considers Value delivery at production level, linked to transformation activities or what needs to be done (the work). Therefore, this concept is easily observable through current LC practices, where Value has been mainly associated to Market and Utility Value. Thus, Last Value can be commonly understood by the supply chain as what customers will pay for products or services (what customers give to achieve an unsatisfied need). 
The two concepts are not discrete but rather exist at either end of a scale. Not every construction project needs to fulfil the aspirations of First Value - indeed few will, but all projects must fulfil the ends defined under Last Value. The intention of this work is to enable the underlying performance of the construction sector to move towards a more considered contribution to society (i.e. to the left on Table 1) by conceptualising the "big picture" or social system. Continuous improvement is a fundamental Lean principle so First Value is intended to form an aspiration rather than a tangible set of criteria; in the way that perfection is a final Lean principle (Womack and Jones 2003). This scale of First to Last Value provides context to the existing thinking on Value found in literature on Lean Design presented in Table 1 below:

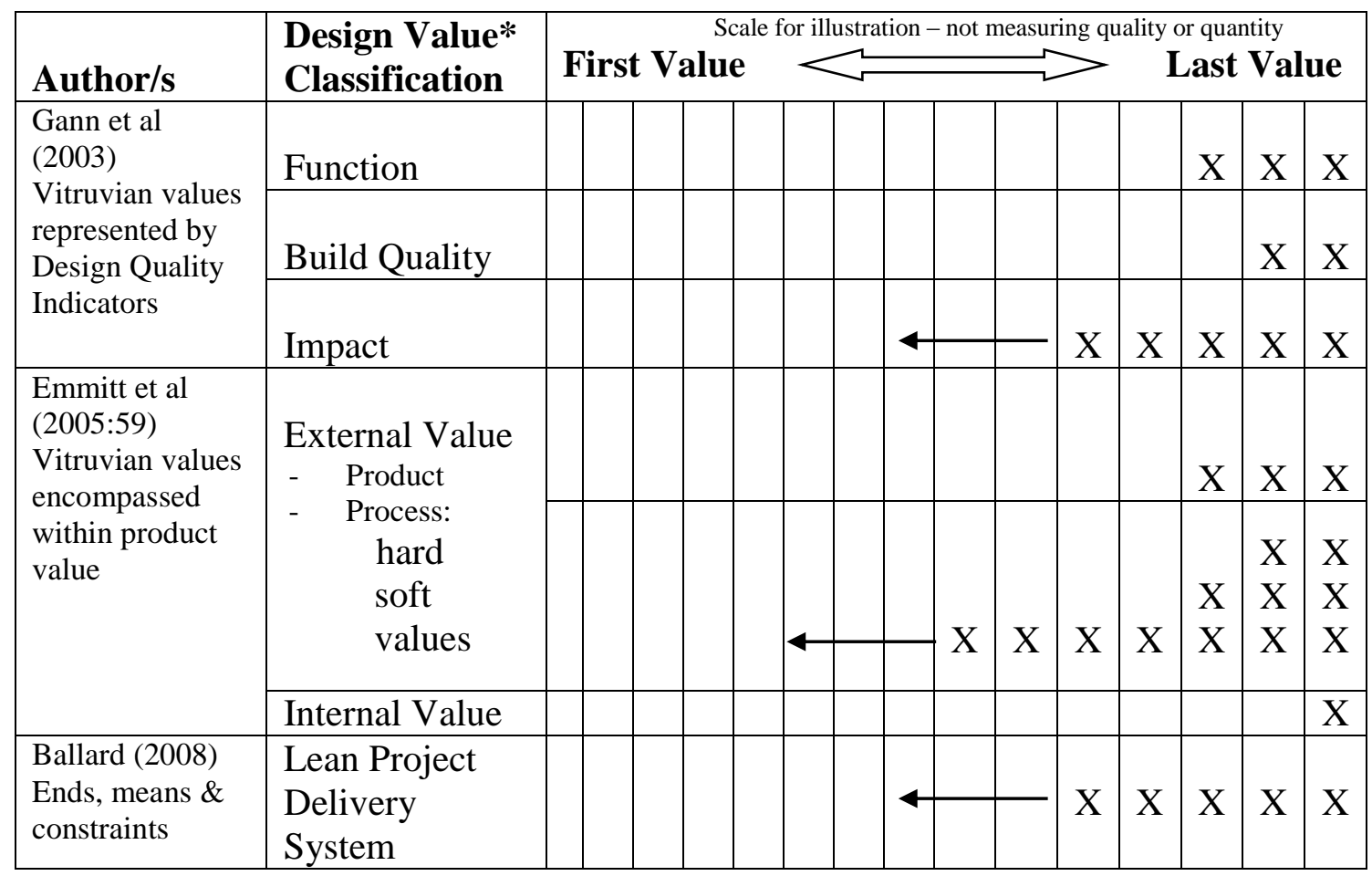

Table 1: Visualisation of First \& Last Value compared to current design Value Key:
$\leftarrow$
this aspect already demonstrates the potential to deliver First Value $\mathrm{X}$ degree to which Value fulfilment goes beyond meeting bill payer requirement
* description of the design values is given below

Product values are commonly understood as "derived from Vitruvian values (firmness, commodity and delight), combined with harmony with the surrounding, environmental issues and buildability." (Emmitt et al. 2005:59). According to Gann et al. (2003) Function, Build Quality and Impact can be the modern interpretation of Vitruvian values. Based on Design Quality Indicators (DQI), the modern terms associated to Vitruvian values can be defined as follows:

"Function: Encompasses aspects of its use, access and space;

Build Quality: Encompasses aspects of its performance, engineering system and construction; and

Impact: Encompasses aspects of its contribution to form and materials, the internal environment, urban and social integration, identity and character." (Gann et al. 2003). 
Emmitt et al (2005:59) go further dividing Value into:

- External value, which is the client/customer value, and the value that the project should end up with and the delivery team focusing on achieving;

- Internal value, by and between the participants of the delivery team.

In addition, external value is sub-classified as:

- product Value demonstrated through the final physical product and related to Virtuvian values and

- process Value is about giving out customers the best experience during design and construction of projects. It comprises:

- 'Soft values' such as work ethics, communication, conflict solving etc. between the client and the delivery team.

- 'Hard values' such as the delivery teams ability to keep agreed time limits, cost estimates, quality of the product and workers safety etc.

- values that come from the actual design and construction process. As an example of this kind of value, renovation works in a kindergarten could be used to teach children about safety, creativity etc and thus generate process value that might not have been evident when the project started out. Learning from participating in the process is another value in this category.

Ballard (2008) places Value as an outcome to the customer derived from the purpose of the development. As such this aligns with the definition proposed by Gann et al (2003) but Ballard expresses this as a combination of end, means and constraints. These classifications provide the current visualisation of Value from a construction industry perspective. The authors cited above also consider a wider set of customers including owner, user and society - but society is commonly represented by authorities as an external constraint not an integral part of the design creation.

To investigate whether First and Last Value have any potential application, two social housing projects in Chile were investigated.

\section{Social Housing Projects in Chile}

As a developing country, Chile provides a fresh platform for designing a built environment that can deliver a measurable contribution to society. Public and private organisations are working under the New Chilean Housing Policy (NChHP) of 2007, to meet housing requirements and to build cities and neighbourhoods that will improve the quality of life unlike previous efforts were focused merely on reducing the housing deficit. The NChHP not only intends to reduce the number of people living in precarious conditions, but it is also concerned about the dignity of those people (Poblete, 2007). This research investigated those features and attributes of the SHP that indicated a wider view of Value and considered the return of Value from construction projects to society as a whole.

A review of the Government document "Fondo Solidario de Vivienda-Manual para dirigentes y familias" (Housing Support Fund - Handbook for Leaders and Families) (www.minvu.cl) revealed three central aspects:

\section{Principles of the NChHP}

a. Reduction of the Deficit, focused on people living in poor conditions; 
b. Guaranty of Quality, improving the standard, the design and construction processes; and

c. Promotion of Social Integration, procuring solutions located in neighbourhoods and cities.

\section{Activities throughout the lifecycle of projects according to the NChHP}

There are three main objectives: 1) delivery of the house, 2) improvement of housing standards, and 3) insertion of families into society. These can be expressed in two themes:

Firstly the house and its attributes:
a. Selection of building site
b. Definition of project budget
f. Revision and qualification of projects (technical, economic
c. Definition of project features and legal)
d. Project's design
e. Post-sale services
g. Planning and controlling construction site activities

Secondly, social insertion:

i. Detection of social problems: delinquency, drugs abuse, unemployment, etc.;

ii. Definition of Social Insertion Plan (SIP)

iii. Family professional training

iv. Insertion of people in social networks (schools, hospitals, transportation, police station, etc.)

\section{Stakeholders responsibilities according to the NChHP}

According to the NChHP, six groups of stakeholders are involved throughout the life cycle of projects. Their responsibilities are defined as follows:

A. Families (householder):

Transmit requirements

Complete savings requirement

Participate in activities of the Social Inclusion Plan (SIP)

B. EGIS (Private organisation dedicated to advising and guiding families on technical and social requirements in order to obtain satisfactory final solutions)

- Represent families' requirements

- $\quad$ Design the project or supervise its design by the architectural team

- Contract building company services

- Coordinate project execution

- Determine completion of quality requirements

- Collect documentation to obtain monetary assistance from the Government (Subsidy)

- Elaborate technical and social project documentation to submit them to SERVIU

- $\quad$ Design and carry out activities related to the SIP

- $\quad$ Manage final reception of projects

- Carry out legal proceedings and register new house in order to authenticate these processes

C. Architectural Team:

Design the project

D. Building Company 


\section{Build the project}

E. SERVIU: Government department responsible for housing programmes and for reviewing Social Housing Projects. It also pays for the EGIS's work and distributes subsidies for building new SHP

Review, qualify and approve projects

Provide funds to pay for technical and social assistance

Distribute monetary assistance from the Government (subsidy)

Carry out or contract technical inspection during construction process

F. Town Council: (The local government)

Collect information about families in social risk

Provide information on building land (cost and availability)

Allow construction of the projects

Approve final reception of the projects

\section{Case Study Projects: Stakeholders activities}

To complement the documentary information about the NChHP, two SHP in Chile were investigated. Neither project was built explicitly using Lean thinking.

1. "Campamento: Vista Hermosa - Un Sueño por Cumplir": Located in the Town Council "Lo Espejo", the project to house 300 families began in 2000. The area was part of the biggest shantytown of the Metropolitan Region of Santiago of Chile. In December 2007, the first 30 families grouped under the committee named "Sueño por Cumplir" received their houses.

2. "Campamento: Lo Boza - Condominio Antumalal": Located in Town Council "Renca", the project was created to house 170 families coming from four shantytowns of this district. In June 2008, these families received their houses.

In order to capture stakeholder experience, eight interviews were carried out with senior members from stakeholder organisations B to F, using two semi-structured survey instruments. Each instrument comprised open-ended questions designed to gain an insight into the context for the consideration of Value.

\section{a) Interview survey 1 :}

Comprised two open-ended questions to identify the particular \& general stakeholder experience:

- In relation to families, which needs are you trying to meet?

- In relation to the Society, which needs are you trying to meet?

The list below summarises the data collected:

- Housing provision

- Provide basic facilities, toilet, kitchen, etc.

- Provide basic infrastructure for further extensions

- Improve families' standard of life (Quality of Life)
- $\quad$ Reduce number of non-paying lodgers

- Protection of vulnerable groups (Social vulnerability/risk)

- Provide public safety

- Minimize urban poverty 
- Avoid stigmatisation associated to neighbourhood's location

- Avoid residential and social segregation

b) Interview survey 2:

Intending to gain an insight into the activities carried out at the early stage of projects stakeholders were asked:

- $\quad$ Based on the job performed, detail the activities carried out in the following stages of the project: new building required, feasibility, scheme design and detail design)

The activities identified were::

- New building requirement:

○ Coordinate activities

- Determine demand

- Provide for participative workshops (e.g. housing design, neighbourhood, equipment, etc.)

- Address families' expectations

- Assess land site alternatives

- Feasibility:

○ Evaluate project costs and feasibility aspects, Technical \& legal studies in relation to the site

- Determine the exact number of families to be included

- Define housing size, model \& urban sketches

- Determine Economical feasibility (Design)

- Scheme Design :

○ Workshops (Housing Design, neighbourhood, equipment)

○ Management of families' expectations

- Elaboration of models to scale and 3D models (Design based on the use of the house)

- Elaboration of specialities projects (sanitation, paving \& electricity)

- Detail Design:

○ Adjustment of Budget-Design

- Approval of final design

- Certification of final solution (Technical \& legal requirements)

- Elaboration of housing plan (technical drawings)

$\circ$ Procurement of edification permissions

\section{First and Last Value in SHP in Chile}

NChHP's principles give the opportunity to visualise Value from a wider perspective. The first two principles (reduction of deficit \& quality) are closely related to Last Value delivery through the provision of a house and its attributes. However, the third principle clearly shows Value delivery to the entire society (towards First Value). Comparison of the First and Last Value concept with data collected describes how these can be seen within the case study projects.

\section{* Last Value:}

The first two principles of the NChHP give the opportunity to address Value delivery at project level (Value associated to product delivery and product attributes - the house). The Chilean experience demonstrates that Last Value can be visualised as:

- Provision of the house; 
- Management of monetary, human and natural resources;

- Improvement of housing attributes (location, quality, materials, function, etc.);

- Management of product attributes in function to available resources (cost \& time);

- Planning \& control of activities (Design \& Construction);

- Stakeholders' involvement from early stage of projects (Provide an interpretation of families' vision on housing expectations).

\section{* First Value:}

The third principle of the NChHP includes Value from a wider perspective. Consequently, the analysis of activities and responsibilities associated to different stakeholders are clearly oriented towards the cure of social issues such as: Delinquency, drug abuse, unemployment, etc. There is a close relationship between SHP and the welfare of the entire population. In the case studies, the construction industry delivers Value to the entire society and the phenomenon where Value is understood as an "oscillating" concept applies and the decisions made will inform future projects. In this way, the Chilean experience demonstrated a move towards First Value which can be visualised as:

- Insertion of low income people to society;

- Less stigmatisation;

- Less social vulnerability \& risk;

- Improvement of public safety;

- Improvement of social environment (aesthetic), etc.

\section{Conclusion}

Lean construction theory indicates that most efforts have been made to deliver Value from a customer-focused perspective, where project control and planning are central activities. Recognition of the need for a softer and wider definition exists and that this should include sustainability and whole life issues - the needs of society are included within these. The First and Last Value approach adds several aspects to the theory so far:

1. That society - considered as human survival and development, encompasses environmental and economic sustainability as society is dependent on these.

2. That Value so far is seen as a self-contained project attribute/set of attributes that can be defined, allowing Value to be visualised along a scale permits wider goals and responsibilities to be recognised and a strategy formulated.

3. That visualising Value on a scale enables a project design to be questioned "how are we doing on the First Value scale?" as design progresses. This pushes design to the left (on Table 1.) by requiring some view of First Value for each project.

4. That visualising Value on a scale (Last to First) moves project design towards increasing Value - aligning with the Lean vision of more for less.

5. That recognising the oscillating nature of Value with the strategy of social goals influencing projects which feed benefit back to society and so on will contribute to a Lean end-end view for the management of the built environment and urban and rural planning.

The investigation of social housing projects in Chile demonstrated the possibility and desirability of developing a construction strategy that delivered a return of Value to 
society. These projects aimed to improve healthcare, reduce crime, increase employment, integrate low income people into social networks, etc and the design was managed accordingly (although not expressly Lean) and provide tangible evidence that social issues can drive development.

Finally, this paper forms part of a research whose objective is to visualise Value from a wider perspective with the objective of returning Value from projects to society as a whole. However, there are questions which need further investigation, for example:

- How does Last Value translate into First Value?;

- Can companies be rewarded other than by payment of money for delivering First Value to society as a whole?; and

- If not, how can payment for First Value be made to better reflect Last Value?

\section{Acknowledgments}

The research reported in this paper is part of an ongoing $\mathrm{PhD}$ of Loughborough University - Department of Building and Civil Engineering. The authors would like to acknowledge the support for this research from all the interviewees involved in social housing projects through the following institutions: Ministry (Sub-Department of Housing Operations - SERVIU Metropolitano), Lo Espejo-Town Council, Architectural company (Elemental), Building company (Simonetti), EGIS (UTpCH-Definitive Housing Area UTpCH), Renca-Town Council, Building company (SIESCON Constructora), EGIS (JUNDEP).

\section{REFERENCES}

Alves, T and Tsao, C (2007) "Lean Construction - 2000-2006." Lean Construction Journal, 3 (1), 46-70.

Amis, J., Slack, T., and Hinings, C. (2002). "Values and organizational change", Journal of applied behavioural science, 38(4), 436-465

Bae, J., and Kim, Y. (2007). "Sustainable value on construction project and application of Lean Construction methods." Proc., 15th Annual Conference on Lean Construction, IGLC, Michigan, USA, 312-321.

Ballard G (2008). „Lean Project Delivery System - An Update“ Lean Construction

Journal, ISSN 1555-1369, 1 - 19

Bertelsen, S., and Koskela, L. (2004). "Construction Beyond Lean: A new understanding of construction management." Proc., 12th Annual Conference on Lean Construction, IGLC, Elsinore, Denmark, 1-12.

Bertelsen, S., and Emmitt, S. (2005). "The Client as a Complex System." Proc., 13th Annual Conference on Lean Construction, IGLC, Elsinore, Australia, 73-79.

Brookfield, B., Emmitt, S., Hill, R., and Scaysbrook, S. (2004). "The architectural technologist's role in Lean Thinking Design with Lean Construction." Proc., 12th Annual Conference on Lean Construction, IGLC, Elsinore, Denmark, 1-13.

Dugnas, K., and Oterhals, O. (2008). "State-of-the-art shipbuilding: Towards unique and integrated Lean production system." Proc., 16th Annual Conference on Lean Construction, IGLC, Manchester, UK, 321-331.

Emmitt, S., Sander, D. and Christoffersen, A. K. (2004). "Implementing value through Lean design management." Proc., 12th Annual Conference on Lean Construction, IGLC, Elsinore, Denmark, 1-13. 
Emmitt, S., Sander, D., and Christoffersen, A. K. (2005). "The Value Universe: defining a value based approach to lean construction." Proc., 13th Annual Conference on Lean Construction, IGLC, Sydney, Australia, 57-64.

Erikshammar, J., Björnfot, A., and Gardelli, V. (2010). "The ambiguity of value." Proc., 18th Annual Conference on Lean Construction, IGLC, Haifa, Israel, 42-51.

Forsberg, A., and Saukkoriipi, L. (2007). "Measurement of waste and productivity in relation to Lean Thinking." Proc., 15th Annual Conference on Lean Construction, IGLC, Michigan, USA, 67-76.

Gann, D. M., Salter, Ammon J. and Whyte, Jennifer K. (2003). "Design Quality Indicator as a tool for thinking." Building Research and Information, 31(5), 318-333.

Glew, D. (2009) "Personal values ad performance in teams: An individual and teamlevel analysis", Small Group Research Journal, 40(6), 670 - 693

Green, S. D. (1997) "New directions in value management." Proc,. Hong Kong Institute of Value Management International Conference: Effective Change through Value Management, Hong Kong, 1-8.

Höök, M. (2006). "Customer value in lean Prefabrication of Housing considering both Construction and Manufacturing." Proc., 14th Annual Conference on Lean Construction, IGLC, Santiago, Chile, 583-594.

Kelly, J., Male, S., and Graham, D. (2004) "Value Management of Construction Projects.", Blackwell Science, Oxford.

Koskela, L. (2000). An exploration towards a production theory and its application to construction ,PhD Thesis, Technical Research Centre of Finland-VTT, Helsinki.

Koskela, L. (2004). "Moving On - Beyond Lean thinking." Lean Construction Journal, 1(1), 24-37.

Koskela, L., Siriwardena, M., and Rooke, J. (2008). "Through-Life management of built facilities: Towards a framework for analysis." Proc., 16th Annual Conference on Lean Construction, IGLC, Manchester, UK, 61-71.

Leszinski, R. and Marn, M. (1997) "Setting Value. Not Price", The McKinsey Quarterly, No 1

Love, P.E.D. and Li, H. (2000). "Quantifying the causes and costs of rework in construction." Construction Management and Economics, 18, 479-490

Poblete, (2007) P-MINVU Primeras viviendas de nueva política habitacional en Región Metropolitana. (http://www.minvu.cl/opensite_det_20071207160817.aspx) viewed 30/04/08.

Thomson, D. S., Austin, S. A., Devine-Wright, H., and Mills, G. R. (2003,a). "Managing Value and Quality in Design." Building Research \& Information Journal, 31(5), 334345.

Thomson, D. S., S. A. Austin, G. R. Mills and H. Devine-Wright (2003b). Addressing the subjective view of value delivery. COBRA 2003, University of Wolverhampton, The RICS foundation.

Thomson, D., and Austin, S. (2006) "Using VALiD To Understand Value from the Stakeholder Perspective", Proceedings of 46th SAVE International Annual Conference, Savannah, Georgia, 1-11.

Thyssen, M. H., Emmitt, S., Bonke, S., and Christoffersen, A. K. (2008). "The Toyota Product Development System Applied to Design Management Workshop Model." Proc., 16th Annual Conference on Lean Construction, IGLC, Manchester, UK, 507518.

Tilley, P. A. (2005). "Lean design management -a new paradigm for managing the design and documentation process to improve quality?" Proc., 13th Annual Conference on Lean Construction, IGLC, Sydney, Australia, 283-295. 
Salvatierra-Garrido, J., Pasquire, Ch., and Thorpe, Tony., (2009). "Value in construction form lean thinking perspective: current state and future development." Proc., 17th Annual Conference on Lean Construction, IGLC, Taipei, Taiwan, 127-136.

Salvatierra-Garrido, J., Pasquire, Ch., and Thorpe, Tony., (2010). "Critical review of the concept of Value in Lean Construction Theory." Proc., 18th Annual Conference on Lean Construction, IGLC, Haifa, Israel, 33-41.

Wandahl, S. (2005). "Value in Building." PhD Thesis, Aalborg University, Denmark.

Womack, J, and Jones, D. (1996) "Lean Thinking: Banish waste and create wealth in your corporation." Simon \& Schuster, New York.

Womack, J., and Jones, D. (2003) "Lean Thinking: Banish waste and create wealth in your corporation." 2ed. Simon \& Schuster, New York. 